\title{
Making Love: Celestinesque Literature, Philology and "Marranism"
}

\author{
$\dddot{\imath}$ \\ Joachim Harst
}

“¡Ay, ay, noble mujer, nuestro gozo en el pozo!” (Rojas 336). Having witnessed her spectacular suicide-Melibea has just killed herself by jumping from a tower-Pleberio imparts the terrible news to his wife in astonishingly inadequate terms. The fall to death of his only daughter - a literal rendering of the exemplary tragic fall of Fortuneis transformed into a commonplace of shattered illusions, devoid of any personal expression. This is true for most instances of passion in La Celestina, be it love, grief or greed: The language of its characters often rings hollow, because of its excessive use of popular phrases and commonplaces-almost every sentence has already been said a thousand times before.

This is certainly not a very original observation. It has, in fact, often been noted that the art of La Celestina consists in its ingenious arrangement of commonplaces. Hearing the utterance of Pleberio which seems to betray his feelings in the double sense of the word-it communicates them precisely by distorting them unfaithfully-it is also not astonishing that Celestina is often read as a document of Early Modern alienation, or more precisely: as the masked expression of alienation and secularization experienced by its supposedly converso authors.

However, this contextualization of La Celestina — vividly described by Stephen Gilman and implicit still in many recent readings of the text-is not free of contradictions. Indeed, Gilman's representation 
of marranism as alienation and loss of identity encounters serious problems when it is confronted with a close reading of the text itself. ${ }^{1}$ But even if Gilman's interpretation cannot be the last word on this matter, it does conduce to the discovery of an important strategy of La Celestina, namely the subversion of the concept of identity which remains essential for any notion of marranism as alienation. In working against any presupposed identity, the text rejects both the idea of marranism as alienation and the tendencies of philological commentary, as long as they intend to identify the author's masked beliefs or opinions (sections 1 and 2 of this essay).

If La Celestina criticizes certain strategies of philological commentary, one might ask further whether celestinesque literature ${ }^{2}$ in turn develops its own philology, drawing upon the radical sense of the term's roots, namely "love/desire" and "logos." Hence, in a second part of this paper, I read Diego de San Pedro (section 3), Feliciano de Silva and Francisco Delicado (section 4), and point out how the individual texts represent love in language. Here, my main focus is the question whether celestinesque literature, working with traditional topoi and subverting patterns of courtly (and Christian) love, attains a notion of desire that is more complex than love-making, the ostensible goal of its protagonists. In La Lozana andaluza, for example, sexual desire is also desire to read-namely, La Celestina. In a quite complex sense, the intertextual relations inherent in celestinesque literature are making "love"; the text enacts philology as an erotic passion, but it also spiritualizes desire in a way that will, in the course of this essay, be determined more precisely.

\section{Literature and philology}

1. Cutting bonds

The general philological problem that inheres in the term "marranism" lies in its implicit discursive framework: the very notion "marrano" or "converso" refers not so much to an independent fact, but to its social and religious framing. It is therefore impossible to talk about conversos and their "loss of identity" from a perspective that does not already presuppose this framework. Indeed, every philologist knows this problem of framing, insofar as his interpretive commentary

\footnotetext{
${ }^{1}$ For a recent overview of philological approaches to the problem of "conversoliterature" see Susanne Zepp 9-25.

${ }^{2}$ I understand the term "celestinesque literature" in the strict sense of (more or less) explicit continuations and variations of La Celestina (see Consolación Baranda).
} 
establishes a framework that produces the history and meaning of the text, thereby retroactively constituting the text itself. In order to show that this analogy between marranism and philology is not a mere coincidence, I will turn briefly to the first known philological engagement with Rojas' text, namely, Celestina Comentada. This work by an anonymous man of law provides the dialogues of La Celestina with learned annotations, citing abundantly from the treasures of classical literature and, more specifically, from collections of legal texts. Certainly, this "commentary" is not a "philological" work in the current sense of the word, although its strategies of identification and authentification resemble some renowned philological studies of La Celestina in the $20^{\text {th }}$ century (Alan Deyermond, Louise FothergillPayne). The anonymous commentator "explains" phrases of the literary text by adducing "sources" that say the same or a similar thing, but he doesn't-as modern philology is wont to do-consider the context of the phrases. Furthermore, the fact that the commentator "explains" phrases of the literary text by adducing titles of decrees and juridical commentaries shows that he does not distinguish rigorously between law and literature; just as the sententious wisdom from La Celestina may be "explained" with reference to current law, the sentences of law in turn are reinforced by their literary application. ${ }^{3}$

Considering the play's plot-the matchmaker Celestina leads Calisto and Melibea to a premarital union-, it is striking that the author repeatedly refers to treatises on marriage. In the Christian tradition, marriage establishes a sacred bond between individuals and hence represents both the bond between God and his People and the binding force of His law. The cut of circumcision that paradoxically represents the first bond between God and his People also symbolizes this ambiguity, the circle being a figure of perfection, the scission a symbol of castration and legalization of desire (Gen. 17). A similar ambivalence is conveyed by the traditional depiction of marital union as a "knot"; thus, Melibea talks of the "ñudos del matrimonio" (304), referring to the marriage that her parents had planned for her. On another occasion, however, the "knot" is mentioned more ambiguously. Calisto, receiving from the hands of Celestina Melibea's precious belt, cries ecstatically: "¡O bienaventurado cordón . . . ! ¡O ñudos de mi pasión, vosotros enlazastes mis desseos!” (186). Clearly, Calisto refers

\footnotetext{
${ }^{3}$ The mutual reinforcement of law and literature is illustrated by the fact that some of the treatises the commentator refers to are themselves collections of citations, especially the important De Legibus Connubialibus by André Tiraqueau (1513), while Giovanni Nevizzano's Sylva Nuptialis (1516/1523) even includes phrases from La Celestina.
} 
to the belt that prefigures his union with Melibea; and on account of its circular figure, he can call it "knots of my passion," stating that it has bound his desires. But "enlazar" does not only mean "to bind"; since "lazo," besides the knot of marriage, may also be a snare that is formed by a knot, "enlazar" can also mean to ensnare someone. Pleberio uses the word in this sense in his lamentation: “CCómo me mandas quedar en ti [mundo halaguero], conosciendo tus falacias, tus lazos, tus cadenas y redes, con que pescas nuestras flacas voluntades?" (341). The "knot" of the union-culmination of Calisto's desire-is also the snare in which he is caught. The law-giving "lazo" resonates with the "lazería" $(146 ; 230)$ of earthly misery and causes the (vividly described) laceration of the protagonist: it makes him fall to death and cuts him into (three) pieces ("su cabeça está en tres partes" 327).

The bawd Celestina only heightens this ambiguity of the bond. She knows how to arouse desire even in stones (103) - the unions she procures are the effect of a deliberate stimulation of desire, and hence they are manifold and changing. ${ }^{4}$ Even without alluding to Celestina's notorious ability to make or "renovate" virgins, the bawd appears as opposed to God, multiplying the fundamental "one" of monotheistic law. In the end, even the commentator feels that, in spite of her legal knowledge, Celestina is a criminal character: He observes that her name is derived "de una palabra latina que es scelus que quiere dezir traicion o maldad;" consequently, she must be a criminal person, "porque los nombres de las cosas o personas an de ser semejantes e correspondientes a las mismas cosas como se prueva en el $\S$ est e aliud institu. de dona" (58). Obviously, the correspondence between words and things, proven by law, is another figure of the legal bond; on account of this bond, the name "Celestina" becomes legible as derived from "scelus," which evidently refers to its breaking. The commentary explains the text by applying a law that is invalidated by the text and its protagonist. Such a contradiction is not accidental; instead, it may be considered a philological dilemma that reflects a general problem of interpretation: In order to read, one has to presuppose that there is something readable, e.g. that there is a bond between words and meanings. The "scelus" in "Celestina" presupposes this juridico-theological framework, since there can be no crime without law. Maybe it is even precisely this presupposition that can account for

${ }^{4}$ For instance, Celestina's famous praise of the "two" versus monogamy: “¿Qué quieres, hija, deste número de uno? Más inconveniente te diré dél, que años tengo acuestas. Ten siquiera dos, . . como tienes dos orejas, dos pies y dos manos . . . . Y si más quieres, mejor te yrá" (206). 
the allusion to the "celestial" that also lies in Celestina's name: Her breaking the law, then, would be just as constitutive for any juridicotheological reading as the cut of circumcision is constitutive for the bond between God and Abraham.

The paradoxical movement of cutting bonds - the framework is only instituted by its breaking-is also pertinent to the problem of marranism. In the following, I would like to show that the term "marranism" in its conventional acceptance implies a theological framework that implies notions such as alienation and martyrdom and is used in philology as a metaphor for certain strategies of reading texts and authors. La Celestina, in contrast, evokes comparable concepts, but only to play with them in a quite heretical way, e.g. depicting the bawd as a martyr. Thus, the text undermines the framework of reading that the term "marranism" establishes and comments on the problem of commentary.

\section{2. "Marranism" and martyrdom}

As I have mentioned before, the terms "converso" and "marrano" do not refer to independent individuals or concepts, but to their discursive framing; by this I simply mean that they imply the perspective of the "true" religion and stable identity-be it Christianity or Judaism. Talking about lost religious identity only makes sense from a position of religious identity, but it is hard to justify just why identity should be a pertinent category in the first place. ${ }^{5}$ Gilman's interpretation of La Celestina, too, inevitably reproduces this framework; indeed, it is implicit in his use of the theatrical imagery with which he describes "converso alienation." Furthermore, by reading his account of the text closely, I would like to show that the type of theater and masking Gilman has in mind inevitably connects alienation to the question of identity; rather than being an obstacle to authenticity, the mask of alienation provides a powerful metaphysical structure to ensure identity. Rojas' text, in contrast, cites these theatrical structures only to lure the reader into the fatal (but significant) misreading that there is something definite beyond the mask.

At first sight, Gilman's notion of alienation seems to be rather simple, drawing on the necessity of dissimulation under the inquisition. In The Spain of Fernando de Rojas, Gilman introduces his understanding

\footnotetext{
${ }^{5}$ There is, however, interesting work being done on the notion of "identity" in literature and cultural history; for instance, the recent publications by Barbara Fuchs, David Nirenberg, and Zepp.
} 
of alienation when dealing with the case of Alvaro de Montalbán, Rojas' father-in-law and another converso. As a man of advanced age, Alvaro de Montalbán was accused by the inquisition of the utterance, "acá toviese yo bien, que allá no sé si ay nada." Wondering how this dangerous slip of the tongue could have happened to Alvaro, Gilman explains that Alvaro must have been "caught off guard," stripped "of his armor of self-vigilance" and "lulled into forgetting that he must never be himself" (83). A couple of pages later, Gilman refers explicitly to a "rigid masking of the inner self" and "unremitting self-observation" necessary when living "in the shadow of inquisition" (85-6).

But even if Gilman's concept of alienation rests on the simple opposition of outer mask vs. inner self, his analysis of the case of Alvaro de Montalbán suggests a more complex problem. Still trying to imagine how the fatal lapsus linguae could happen, Gilman emphasizes the fact that (according to the inquisitorial records) it was uttered as a reaction to the commonplace statement of a Christian priest: "Todo es burla syno ganar para la vida eterna” (82). Alvaro's imprudent utterance thus seems to be an impatient reaction to the "ready-made" language of the Christian, a vigorous affirmation of individuality in front of a language that bears no traces of its speaker: inquisitorial Spain "was a world of simulation and camouflage interrupted by outbursts of irrepressible authenticity" (104).

Thus, the sentence that betrayed Alvaro must have been the only true utterance in a world of false appearances. This facile opposition of commonplace and authenticity, however, is undermined by Gilman's own observations. For Gilman goes on to show that Alvaro's utterance itself is a topical saying-in fact, Gilman calls a similar saying a "counter-commonplace of skepticism and resigned disbelief" (91) that was so popular that it, in turn, became a "standard accusation" for the Inquisition (92). But if Alvaro's supposed "outburst of authenticity" is nothing more than a topical remark, it is in no way closer to the "inner self," not the real "grimacing face," but another mask-and, unfortunately, the wrong one to wear on this occasion.

I have followed Gilman's exposition of the case of Alvaro de Montalbán in detail to point out the logic that underlies his understanding of alienation and, consequently, his representation of the "marrano." Turning to the play itself, I would now like to ask whether it supports the opposition between masked appearance and concealed, but true essence. To be sure, the mourning cry of Pleberio-“el gozo en el pozo"-doesn't seem to match this categorical distinction: Even in the moment of most personal grief, Pleberio betrays his feelings in 
a proverbial rhyme; far from provoking an "outburst of irrepressible authenticity," the authentic affect manifests itself in the redundancy of rhyme.

The most vivid hint here is the (topical) love of the protagonists. All of a sudden, love for Melibea strikes Calisto out of the blue, giving the reader no opportunity to understand this "profound" feeling in psychological terms; instead, Calisto's passion is betrayed as a caricature of courtly love, lacking any psychological depth. ${ }^{6}$ Melibea, in contrast, seems to be sincere in her abrupt refusal of Calisto's advances and Celestina's intervention; but when she later admits her longing for Calisto and accepts the help of the go-between, her previous chastity appears as just another mask of desire. The impossibility to distinguish between essence and appearance is expressed most poignantly when Calisto in his first lines praises God for arranging a meeting with Melibea, thus establishing an analogy between God and bawd-and a paronymic relation between the celestial and Celestina (86).

For this reason, one may suspect that Rojas' play undermines Gilman's theatrical model of alienation: There is no psychological depth to the characters, if not in the superficiality of their language; consequently, there can be no authentic essence hiding behind the mask, if it is not manifest in the mask. This contradiction between the strategies of the text and the framework of its reading-marranism-is heightened when one turns to a second concept that is central to $L a$ Celestina and Gilman, namely, martyrdom as topos of courtly literature, as metaphor for the sufferings of the alienated and as an image for a Christian way of reading, which will turn out to be rather corporeal.

The weekly attendance of mass, Gilman feels, must have been a "shared Sunday martyrdom" (97) for every converso. The empathetic, if inconsistent, metaphor for the "torment" of a "life under constant observation" (94) alludes once more to Gilman's theatrical model of "alienation" and combines it with an important complex of Neostoic ideas that is also present in Rojas' text. It is well known that Rojas borrowed most of the proverbs and rhymes that he lends his characters from the Index to the works of Petrarch, a convenient source of Neostoic wisdom that was very popular at the time (Deyermond). Hence it may not astonish much when Gilman discovers that the author aims at a Stoic truth concerning existential loneliness. His detailed analysis of Pleberio's lament comes to the conclusion that "Pleberio is the ulti-

\footnotetext{
${ }^{6}$ Nicasio Salvador Miguel employs this observation in his blistering rebuttal of $L a$ Celestina's "presunto judaísmo" (168, 172; see also Gregory Kaplan 119).
} 
mate Stoic subject" (382), who betrays the agnostic assumption of a "Godless universe" (377). "Or at best," Gilman immediately corrects himself, "assuming that behind the masks of Fortune there lurks some sort of overseer, he is capricious and heartless" (377).

Gilman's spontaneous self-correction is significant for two reasons: First of all, it repeats the imagery of theater once more, combining it with hints of voyeurism and torture; but more importantly, it implicitly acknowledges the fact that Stoic philosophy requires some kind of divine onlooker, be it a benevolent God, a vicious tempter, or, later, the inquisition. For Seneca understands existence as a spectacle in front of divine providence. In his treatise De providentia, for example, he calls the stoic hero's fight with fortune a "spectaculum dignum ad quod respiciat intentus operi suo deus," a spectacle worthy to be noticed by God as he contemplates his work (10). And indeed, such an uninvolved spectator is necessary if one wants to claim that the subject may remain true to itself in a world of fleeting accidents and constantly changing appearances: Who else should be able to acknowledge and testify to its identity? The notions of "identity" and "constancy," so important for any idea of Stoic martyrdom, implies a theatrical setting with God as spectator. That's why this model of theater with its uninvolved spectator always presupposes a theological framework. ${ }^{7}$

Certainly, La Celestina's implicit allusions to Stoicism may sound rather agnostic to inquisitive ears. Still, it is important to note that Stoicism is one of the most important sources for the Christian understanding of the martyr. His steadfastness and refusal of conversion is, just as in Seneca, the reason why the divine authority should care to look down on him-and in a quite morbid expression by the German Andreas Gryphius, the martyr's dismemberment under torture is supposed to "reveal what is inside," namely, a true Christian. ${ }^{8}$ For God reads the faith of his subjects in their entrails; he has to see whether his subjects are faithful to him, and if they are, their death is transfigured into victory. The Christian understanding of the martyr, then, represents God as the eternal witness and ultimate judge of steadfastness, identity and constancy; his transcendent judgment overrules any earthly sentence, as is written in the Gospel of Matthew: "Blessed [are] they which are persecuted for righteousness' sake [héneken dikaiosynēs], for

${ }^{7}$ For a more detailed analysis of the theatricality of martyrdom, see Harst (forthcoming).

8"Die Presse der Trübsal bringet hervor/ was in diesem oder jenem Hertzen verborgen” (Gryphius 78; see also 172). 
theirs is the kingdom of heaven" (Mt 5:10). The one who is unjust in the eyes of the world (and therefore executed) becomes just in the eyes of God- "he confessed and did not deny" is a topical formula in Christian testimonies of faithfulness.

Returning to La Celestina, it is important to note that the text does not simply quote many Stoic and Christian commonplaces; it employs them in a way that undermines their implicit model of theater and spectatorship. This could not be more evident than in the famous scene in which Celestina cites the line from the Gospel of Matthew that I have just quoted. Telling Pármeno about the punishment of his mother for being a witch, she adds the consolatory words "que bienaventurados son los que padecían persecución por la justicia y que aquellos posseerían el reino de los cielos" (199). Commenting on this line, Gilman remarks that Celestina's translation of héneken dikaiosynês renders the phrase ambiguous, for it may be understood both as "persecuted for righteousness' sake" and as "persecuted by justice" (93). And of course he is right when he notes that the Christian idea of martyrdom is perverted in Celestina's mouth, since in her words every base criminal could claim a spot in heaven: The simple fact of being persecuted by Justice would be sufficient to stage oneself as martyr. In fact, this perversion is not even unique, but has become a commonplace, repeated in, among other texts, Lazarillo de Tormes, where the narrator tells the story how his father has been "persecuted by justice" for being a thief, adding ironically that he "confesó y no negó, y padesció persecución por justicia” (14).

More importantly, however, the quoted commonplace is not only a perversion of Christian ideas on martyrdom; it is also an inversion of its theatrical model. When Celestina speaks of a "persecución por justicia," she ambiguously identifies earthly law and divine justice, just as Calisto identified God with the bawd. Again, the effect is that God as transcendent spectator and judge is dislodged into the immanence of the world; the framework has become part of the staging. Hence there is no instance left to distinguish definitely between masks and faces - the mask is the only face that remains. To try to discover and reveal what lies in secret behind it, is not only erroneous, but also unwillingly sarcastic, for it means reproducing the very same structures of questioning that the inquisition employed to supplement its lack of divine knowledge (Nirenberg 401; Zepp 22-24). At the same time, it is a quite comprehensible reaction to a text whose exposed superficiality invites a search for a deeper meaning on the level of the author. Superficiality, then, can be considered as a literary strategy in its own 
right; thus, for example, one might appreciate the many oblique allusions to Calisto's and Melibea's Jewish heritage, not as an expression of the author's social unease, but as hints that lure the reader in an inquisitive position, trying to figure out which one of the two is the true marrano (Kaplan 118). In this perspective, the text would not depict the situation of conversos, but it would invite a certain highly problematic kind of philology-only to subvert it, superficially.

The confrontation of marranism and philology as worked through in the above paragraphs, however, does not exhaust the problem. So far, I intended to suggest that La Celestina is "marrano literature," not so much because it was allegedly written by conversos, but because it invites readings that are based on the hermeneutical pattern of marranism. At the same time, the text subverts this pattern, as the example of the burlesque perversion of martyrdom has shown, and thus superficially undermines this type of philology. In the following parts of my paper (sections 3 and 4), I would like to follow the topos of martyrdom and its connection with love more closely, reading Diego de San Pedro, Feliciano de Silva, and Francisco Delicado in order to unfold how celestinesque literature develops a positive notion of philology.

\section{Literature as Philology}

3. The Lover's Martyrdom

Feliciano de Silva's Segunda Celestina picks up the topic of martyrdom at a decisive point. The servant and "rufián" Pandulfo makes fun of the passion his master Felides feels for Polandria and the hope that he invests in Celestina's mediation by comparing his situation to the "martír Calisto"; to which Felides responds, that he would be only glad to "passar su martirio" if only God were to grant him the same "gloria" as Calisto (187-88). Obviously, Felides hints at the nightly rendez-vous the lovers held in Melibea's garden and the quite carnal "gloria" Calisto must have experienced there. But at the same time, he cites an important topos of courtly literature-the lover as martyr - that puts love in an imitative relation to Christ. The following section of my paper intends to show how three texts surrounding La Celestina deal with this transcendent dimension of love.

At first sight, Diego de San Pedro's "novelas sentimentales" are exemplary texts about courtly love (San Pedro 153-55). It is certainly true that the spiritual and even religious dimension of love is 
most prominent in these texts; ${ }^{9}$ at one point, for example, Arnalte composes an "invocation of Virgin Mary" (215-33) in which he uses Mary's mourning for Jesus "as paradigm for the grief felt by the courtly lover" (216n116). However, while the pious overtones of the song may give the impression that it is a "fervent religious declaration" of its author (216n116), the identification of Virgin and lover leads to some rather secular consequences. The most obvious fact is that the focus of the passion has been displaced from the sufferings of Jesus to the mourning of his mother; thus, Mary's love for her son and bridegroom (222) can be depicted as a spiritual passion. ${ }^{10}$ The corporeal passion of Christ is replaced by the passion of love, so that Mary becomes the first Christian martyr. ${ }^{11}$ This is, to be sure, not explicitly stated, but the imagery of the text leaves little doubt: The Virgin concludes her song with the line "mi vivir será morir" (229), just as Leriano is wearing a "corona de martirio" (73), so that the life he spends in lovesick suffering becomes his martyrdom (86), and Arnalte repeatedly describes his mourning as death in life (157, 180, 237). Mary's pious love adopts the idea of martyrdom and inverts its basic structure: Here, steadfastness of faith is not proven by death, but by a life that has become death; if life, however, is a continuous death, then the sacrifice of Jesus and its imitation by the martyr has lost its salutary effect. ${ }^{12}$ The immanentization of the idea of martyrdom is vividly represented by the ritual of mourning that Arnalte performs after he is bereft of Lucenda forever: With the constancy of a ghost, he chastises himself from midnight to the break of dawn, while his castle resounds from the compassionate cries of his servants (157-58). If the martyr becomes a specter, then every hope for resurrection is lost indeed; death is no longer the absolute limit and threshold, but has become indefinite repetition.

This problem is also manifest in the most conspicuous stylistic traits of the novel; ${ }^{13}$ namely, the abundant use of antithetical statements

${ }^{9}$ Keith Whinnom, from the perspective of Cancionero-lyrics, makes strong objections against the alleged spirituality of "love" in Diego de San Pedro; however, I do not think that here or elsewhere in literature "love" could come to be "ni más ni menos que el amor sexual" (La poesía 25 ).

${ }^{10}$ For the general context of this duplicity of "passion" see Erich Auerbach.

11 "Estas llagas que en notarlas/ renuevo mi mal en ellas,/ yo padesco, sin pasarlas,/ mayor dolor en mirarlas/ que no vos en padescerlas;" (San Pedro 227, emphasis mine; see also below, note 12).

${ }^{12}$ It is significant that, although Mary knows the reason for Jesus' death, she does not anticipate his resurrection and possible reunion with her: "Con esta muerte presente,/ fijo, por mando del Padre,/ dais salud enteramente/ a toda la humana gente/ y matáis a vuestra madre" (224, emphasis mine).

${ }^{13}$ For a stylistic analysis of San Pedro's prose, see Whinnom, "Diego de San Pedro's." 
and their condensation in oxymoronic phrases. Especially the representation of love as 'passion' involves the contradictory conjunction of opposites; thus, it internalizes any radical distinction, as is evident in the elegantly enigmatic motto that governs the novel: The phrase "porque no muero, muero" (237) is the subscription to a narrative world in which any opposition and in consequence any absolute limit, any potential of transcendence has been internalized in an elegant play on words. It could even be argued that Diego de San Pedro's obsession with paradoxical figures compares the medium of language to the binding force of love and its "leys enamoradas": Just as in Cárcel de amor the narrator plays the role of mediator between Leriano and Laureola, language itself serves in Arnalte y Lucenda as tercera, an instance that mediates oppositions and procures (illicit) unions.

This elegant rhetoric of love is parodied by Silva's La segunda Celestina, in which Felides deplores the "laws of love" with the words: " $\mathrm{OH}$ amor, que no hay razón en que tu sinrazón no tenga mayor razón en sus contrarios!" (114). Silva's congenial imitation of Diego's language has become famous since Cervantes quoted it in his Don Quixote, adding maliciously that "con estas razones perdía el pobre caballero el juicio, y desvelábase por entenderlas y desentrañarles el sentido" (114). The frenzy of courtly love is not only expressed by language, it is engendered and mediated by it; but while Diego's novels confine themselves to internalizing its paradoxes, the continuations of $L a$ Celestina, as I will argue next, produce a dynamic of transcendence that is represented in the prostitute as martyr; the process of satirical imitation, in turn, may be considered as another kind of philology.

\section{Celestina's gospel}

The philological dimension of the celestinesque novels is apparent in Silva's La segunda Celestina, since the text presents more than a mere continuation of the story: reading it implies a rereading and rewriting, in short: an "emendation" of La Celestina (Silva 48). The most prominent example for Silva's reworking of Rojas' novel is the "conversion" of Celestina, namely the idea that the bawd survives the assault by Pármeno and Sempronio, hides herself for some days in the house of an archdeacon and then returns home, affirming that God has sent her back to earth in order to expiate her crimes and work for the common good. While the people seem to believe in the close relation between God and bawd, the servants and ruffians are less convinced of her sacred mission, making fun of the holy procuress, calling her an angel of love (187), her counsels "el evangelio 
de Celestina" (275). They thus criticize the fictional "emendation" of her character.

A second aspect of the text's inherent literary criticism is the characters' awareness of idiomatic conventions. Here it is Pandulfo who stands out in the rhetorical criticism of his master, telling him that his love-letters and songs are simply poorly written: "Por el Corpus Domini, esto haze a estos cavalleros jamás alcançar muger, que todo el tiempo se les va en elevaciones" (219; see also 270). It is thus, once more, the language of courtly love that accounts for its lack of consummation. Trusting his own recent success, Pandulfo suggests that he should write the next letter to Polandria in Felides' name, which would seduce her without any question, "si tú con tus retóricas no dañas mi filosofía natural" (224) ${ }^{14}$ A later scene, however, presents Polandria and her servant, laughing heartily at the letters' jargon, realizing immediately that its author can by no means be Felides (365-66). Even more revealing, however, is Felides' laughing reaction to Pandulfo's suggestion: "Aunque otra ganancia no se saque destos amores sino ésta, yo doy por bien empleada mi pena” (221). Like Calisto, Felides is a caricature of courtly love, but in contrast to his literary predecessor, he can see himself ironically, too, and thus has a dim awareness of his literary role.

On a more general level, most of the characters and the text as a whole display this kind of literary and generic consciousness, as the expanded focus of the work already suggests: While the plot in $L a$ Celestina focuses mainly upon the love-story of Calisto and Melibea, in Segunda Celestina the focus is multiplied, presenting the procuration of several unions, their intertwining stories, their linguistic differences and rhetorical similarities-and although each social level is characterized by its own idiomatic conventions, all characters use the same commonplaces to attain their respective ladies. Silva creates a literary universe of love, in which every couple is an element for itself and a reflection of the universal conventions of (literary) love, shared with all other couples. His text therefore is an example of the general philological character of the celestinesque continuations: in continuing a story and subjecting itself to its rules-if only to partially break them-it reflects upon its generic character, rhetorical conven-

\footnotetext{
${ }^{14}$ Pandulfo's "filosofía natural" is quite simple; to understand its full significance, it is important to note the double meaning of "natural," which also refers to "sex," as is most evident in Lozana's maxim: "el coño de la mujer . . . no debe estar vacuo, según la filosofía natural” (Delicado 461, 464). See also Claude Allaigre's commentary on the words "natura" and "natural" in his introduction (61-71).
} 
tions and linguistic peculiarities. It thus displays the intimate relation between love and language inherent in philology, while Delicado's Lozana Andaluza, as I will show next, proceeds to enact it.

Although in some respect comparable to Silva's continuation, $L a$ Lozana andaluza takes a completely different approach to the language and legacies of Celestina. It shares with Silva's text the multiplication of couples, but it increases the number of unions in such a way that any plot drowns in the sheer number of characters (supposedly 125) and scenes (at least 67). As it integrates persons from the most different social spheres and ethnic backgrounds, it characterizes them by their respective idioms, but has most of them use the same code, namely the double language of the Cancioneros with its (more or less) hidden erotic significance. ${ }^{15}$ From the beginning, the author-very much present in the text-does not really care to tell a coherent story, but presents fragmentary scenes in which he combines erotic and literary allusions. Lozana, for example, claims that her grandmother has taught her to weave ("tramar")—and even if one doesn't notice the (conventional ${ }^{16}$ ) duplicity of the word, it becomes rather obvious when Lozana adds that she carries her needle case with her but still lacks a needle (Delicado 180). Even the names of places and persons are encoded: consider, for example, that the birth place of Lozana's 'first' lover is "Ravenna"; and that he is traveling to "Cáliz" when he meets her; ${ }^{17}$ furthermore, his name "Diomedes" heralds his qualities as lover since it can be read in Spanish as "Dio(s)-me-des"-give it to me, God.

While it is important to recognize the duplicity of Delicado's language, it is also essential to note that its decoding does not reveal any single "true" meaning of his text. In contrast to La Segunda Celestina, in which the erotic meaning of seemingly innocent phrases is often made explicit afterwards, ${ }^{18}$ La Lozana does not translate its language for the reader; thus, a strict distinction between literal and metaphorical meaning is impossible, and every word remains potentially double. ${ }^{19}$

\footnotetext{
${ }^{15} \mathrm{On}$ this topic see Ian Macpherson; Whinnom, La poesía; and more particularly Allaigre, who presents a stunning analysis of Delicado's code in the introduction to his edition.

${ }^{16}$ It is explained as such by Pandulfo: "Cuanto más que yo te tramaré el hilado esta noche con Quincia de suerte que no se pueda errar la tela" (Silva 206). Furthermore, 'weaving' is a common metaphor for writing.

17"Ravenna" can be associated with "rabo," 'tail, penis,' while "Cáliz" means 'vase' (Allaigre 101).

${ }^{18}$ See notes 16 and 20 for two examples.

${ }^{19}$ In a similar sense, Whinnom emphasizes the essential and irreducible ambiguity of Cancionero-lyric. In his presentation, the poems do not hide their erotic undertones
} 
At the same time, the text uses explicit imagery so often that one cannot maintain its "love" is hidden. Rather, encoding and decoding itself become an erotic activity, so that the text is suspended between a crude realism and an ingenious literalism. The well-known anagram "Roma/Amor" (Delicado 480) only confirms Delicado's intention to double reality (as incorporated in the "eternal city") with a superficial erotic meaning.

This erotic process of reading is related to the text's literary predecessor, when Lozana asks Silvano to read La Celestina to her. To Silvano's question whether she possesses the book, she answers: "Señor, velda aquí, mas no me la leen a mi modo como háreis vos. Y traé vuestra vihuela y sonaremos mi pandero" (399). Silvano reacts with the enigmatic phrase "contempláme esa muerte," which is in turn illustrated by a woodcut that shows two persons meditating upon a skull. The conventional emblem of memento mori seems in no way connected to the contents of the preceding lines, just as Silvano's phrase seems to lack any relation to Lozana's words. One could also wonder why Lozana wants Silvano to bring his "fiddle" and play her "tambourine," when she just asked him to "read" La Celestina to her. But in celestinesque language, musical instruments are closely connected to sexual activity; ${ }^{20}$ hence, the phrase could invite Silvano to "play" on Lozana, thereby also transforming the meaning of to read: "mas no me la leen a mi modo" now hints at the possibility that for Lozana, reading-and especially reading La Celestina-is an erotic activity.

While this reading of the scene also allows an interpretation of the enigmatic "contempláme esa muerte"- "death" is a commonplace metaphor for "orgasm" (Whinnom, La poesía 34-37) —it also amplifies the discordance between text and illustration to an undecidable ambiguity, since the image obviously affirms the literal meaning of the phrase. Without claiming to untie this paradoxical knot, I would like to stress that La Lozana carries the ambiguity of the lover's "death" as represented in La Celestina - both a parody of courtly love and a kind of reprobatio amoris - to extremes, denoting at the same time a sensual climax and an object of spiritual meditation. In this sense, La Lozana

under a mask of innocent images; rather, they delight in saying (at least) two things with one word (La poesía 37, 46).

${ }^{20}$ This is made explicit by a comment of Pandulfo: "que no de balde dize el proverbio que quien las sabe, las tañe, como yo he tañido esta noche a Quincia, que queda, por cierto, tocada de manera que hará otra música que tu romançe en latín, tocado en la vihuela con sus comparaciones" (Silva 222, emphasis mine). The proverb is repeated twice in La Celestina (126, 172). 
posits a strict antithesis to courtly literature as previously discussed: In Diego de San Pedro, living is dying, death has pervaded life (and love) so completely that the lover becomes a specter; in Delicado, in contrast, reading a reprobatio amoris like Celestina can lead to a sexual act culminating in "death"-but because this "death" is quite ephemeral, it also is an adequate object of meditation. To put it more concisely: Diego's language performs a gesture of immanentization, resulting in the ambiguous union of opposites, while in Delicado the individual word is the site of desire, split into two contrary significations, its immanence transcended.

The dynamic of transcendence inherent in La Lozana's erotic philology is condensed in the representation of the prostitute as lawyer, healer, saint and martyr. From the very beginning, Lozana is depicted as skillful in any kind of "pleito," helping her mother to do business in several cities (175-76). Certainly, what exactly "pleito" means-juridical process or erotic strife-remains ambiguous, since the author's announcement of the legal sources of his narration is not quite clear itself: Given the double meaning of "natural," his affirmation that the story is "sacado del jure cevil natural" (175) may also hint at the peculiar understanding of "jure natural" as "law" or even "rent of sex." That Lozana's biography is closely related to that kind of "natural law" comes as no surprise, but it also calls attention to the ambivalence of law, its "pleitos," "contractos" and "ñudos," whose double significance is spelled out in a later scene when Lozana affirms that she knows more about the "jure cevil" of her "basket" than the learned lawyers can ever read in the code (457). The ambivalence of "law" culminates in the author's prediction that with the sacco di Roma "quemaran los publicos y aprobados o canonizados ladrones," namely "los registros del jure cevil" (299). Both the registers of law and the "registrars" 22 of the "rent of sex" will burn as "canonized thiefs," highlighting once more the intimate connection between crime, law, and saintliness.

But the prostitute also bears more explicit marks of holiness. Many of her activities in Rome are described as the miracles of a saint, her most popular wonder being healing the lovesick by laying hand upon them (473). Certainly, here again her deeds and counsels are as ambiguous as ever-Corydon, a boy who seeks her help, responds to her question “¿Me diras celestial?" with "ce-les-ti-nal" (437)—and

\footnotetext{
${ }^{21}$ The latter interpretation is put forward by Allaigre, who explains the phrase as "renta vil del sexo" (75). For "natural," see above note 14.

${ }^{22}$ Lozana is an "alquivio de putas," an "archive" of whores (442): She "registers" any sexual activity and its "rent."
} 
even more so since lovesickness literally implies the venereal disease, from which many characters, as well as Lozana herself, suffer. That the healer is lovesick herself, however, is no reason for her not practicing, as she tells a suffering "canonigo": "deja hacer a mi, que es miembro que quiere halagos y caricias, y no crueldad de medico" (286); he, in turn, recognizes in her scarred face the traces of charity, stating that she must be "mas habile . . que Santa Nefija, la que daba su cuerpo por limosna" (284). The same comparison returns when Lozana is duped by Trujillo to satisfy him without payment and thus comes even closer to "Santa Nefija, la que murió de amor suave" (412).

With the "death of sweet love," Delicado's language returns to the register of courtly love, but only to double it once more: the Christian charity of St. Nefija is crowned by the death of martyrdom. In the same vein, the syphilitic prostitutes of Rome are compared to triumphant generals whose glory is augmented by their wounds, the scars of lovesickness become a "corona de flores," a traditional image for the wounds of Christ (392-93). This ambiguity is amplified when the "author" refers to his sickness as "pasión" (485) and its medicine as "leño salutífero" (439), a commonplace metaphor for the Cross. Both the suffering and the healing prostitute would become figures of Christ.

Thus, the transcendent dynamic of the text's erotic philology not only resonates in the double meaning of "death," but also in its play with Christian commonplaces; both indicate that "love" in Delicado means more than "natural sex"; it also incorporates-in the literal sense of the word-a transcendent impetus, which is fueled precisely by the undecidable duality of the word: While in Diego de San Pedro everything, even life itself, has been absorbed by death, there is always a beyond in Delicado's text.

This is also true for the vision of paradise with which the narrative ends. Even if Lozana's claim that she will enter paradise "because it has three doors" were not suspicious, ${ }^{23}$ her promise that she will catch the peace that reigns in Heaven and send it back to Earth remains ambiguous: "la enviaré atada con este ñudo de Salamón, desatala quien la quisiere" (480). The "knot of Salomon," illustrated by another woodcut, conflates the "Seal of Salomon" and the "Gordian knot"; while the former is the Star of David, i.e. the sign for the bond between God and His People, the latter is a symbol for unsolvable difficulty. The problem of "union" in its religious, legal, erotic and literary aspects,

\footnotetext{
${ }^{23 " Y o ~ q u i e r o ~ i r ~ a ~ p a r a i ́ s o, ~ y ~ e n t r a r e ́ ~ p o r ~ l a ~ p u e r t a ~ q u e ~ a b i e r t a ~ h a l l a r e, ~ p u e s ~ t i e n e ~ t r e s " ~}$ (480). "Puerta" is also a metaphor for the body's orifices; the otherwise unjustified number of "doors" reinforces the ambiguity (231).
} 
one of the main topics of celestinesque literature, is resumed and condensed in a "knot" whose name is reminiscent of the star-shaped syphilitic scar on Lozana's forehead. ${ }^{24}$ But if Lozana bears the "seal of Solomon" precisely because she transgresses every law except for the "natural" one, then again the divine bond would be constituted in its breaking. But here, in contrast to La Celestina, the suffering of the outcast is at the same time the glory of the saint; a paradox which is, I would like to conclude, based on the text's philological strategy to let desire work in the single word and to open it for contradictory significations. Thus, the fatality and blessing of any bond could be called the "gospel of Celestina"-according to her reader Lozana. This conclusion is supposed by the text: In the epilogue, the author "apologizes" for having written La Lozana: "siendo atormentado de una grande y prolija enfermedad, parecía que me espaciaba con estas vanidades" (485). The painful "pasión," if not martyrdom, that the author suffers probably is nothing else but lovesickness; its remedy, he adds, is indicated in his treatise on the "leño de India," the salutary wood, which is ambiguously identified with the "tree of vanity": "como vi coger los ramos y las hojas del árbor de la vanidad a tantos, yo que soy de chica estatura, no alcancé más alto: asentéme al pie hasta pasar, como pasé, mi enfermedad" (485). Thus, the "remedio" for the author's sickness seems to consist less in the content of his "tratado" than in the process of writing itself, described as a pastime and "vanidad" (485). But if the "tree of vanity" is the "salutary wood"-a conventional Christian reading - then the "vanity" of love and writing is at the same time the remedy for its "sickness." The erotic act of writing La Lozana (that is, to read and rewrite La Celestina) is salutary philology.

\section{Conclusion: Marrano Philology?}

I have argued here that La Celestina invites reading strategies that resemble inquisitorial questioning, but at the same time undermines their framework, so that the text comments upon the philological problem of interpretation and commentary. The same problem is staged in La Lozana andaluza, when three converso-women try to read Lozana and determine whether she is "one of us" or not (196). Lozana's ensuing speech seems to reveal her as a conversa (200), and modern philology tends to follow this judgment; the women, however, revise

\footnotetext{
${ }^{24}$ This scar is also a reminiscence of Celestina's "cuchillada," the scar that officially marks her as criminal and is called in the Cancionero de Obras de Burlas a "seal of Salomon" (Allaigre 142).
} 
their opinion soon enough, stating that Lozana has no stable identity, but converts mimetically to the religion of her partners: "Con los cristianos será cristiana, con los jodíos jodía, y con los turcos, turca . . .." (203)..$^{25}$ This is, I would like to suggest, more than a mere statement concerning the prostitute's adaptability to her clients; it also refers to the problem of reading "converso literature": to read literature in search for the religious identity of its authors entails strategies that are just as misleading as the women's questioning of Lozana. What is more, celestinesque literature ironizes this kind of reading and contrasts it with philology as a conscious reworking of an erotic genre, a deliberate staging of language as the medium of love and a literary desire that is fueled precisely by the infinite conversions of words and characters: In San Pedro, a highly rhetoricized language of antithesis and oxymora mediates the contradictions of courtly love, just as the letters mediate between the lovers (section 3 of this essay); in Delicado, the individual word becomes the site of an irresolvable conflict, torn between religious and carnal connotations (section 4). In both cases, however, love is more than a mere topic of the text-rather, it is produced (in the theatrical sense of the word) in its language: these texts are making love. In this sense, love is the object of Silva's revision of Celestina, which, in turn, yields its comic effects precisely by confronting different registers of love-language (sections 3 and 4).

While this understanding of love and literature makes ironic use of religious topoi, it does not confine itself to a simple overthrow of Christian tradition. To the contrary, I have shown that the topos of martyrdom, for example, both represents a theatrical model to be subverted (section 2) and serves as a means to deal with the desire for transcendence: In Diego, the lover is a martyr precisely because he doesn't die; but if living means dying, then death has lost its status as an absolute frontier, and the world of supposedly spiritual love becomes a melancholic world of ghostly immanence (section 3). Delicado's literary strategy, in contrast, consists in a radical duplication of a word's actual meanings, so that "death" can connote "orgasm," "vanity" and "death" at the same time (section 4). The important point here is that neither of these meanings is predominant; the spirituality of Delicado's text lies in the radical openness of his words and the resulting infinite dynamic of transcendence. Here, desire exceeds the word, while in Diego it is contained in the rhetorical figure.

\footnotetext{
${ }^{25}$ See 1 Cor 9 , where Paul describes his missionary practice as assimilation to the religious customs of the people: "And unto the Jews I became as a Jew . . . . To them that are without law, as without law . . . To the weak became I as weak . . . And this I do for the gospel's sake" (19-23).
} 
If celestinesque literature is philological, the question might impose itself whether this particular understanding of philology, with its predilection for ambivalence, subversion and irony should be called "marrano philology." But doing so would only reproduce the contradictions of Gilman's reading by trying to supply an identity (albeit under the title of alienation) for an effect that consists precisely in its endless versability. Gilman's book, I think, exposes the inherent contradictions, if not the utter impossibility of the term "marranism" in an exemplary way; but since it is implied by the literary strategies of Celestina and celestinesque literature (e.g. in the allusions to the possible Jewish heritage of Calisto and Melibea), the term and its hermeneutical problematic cannot be completely abandoned by philology. This is why it must prove its relevance and rigor by disappearing in the act of reading.

Bonn University

\section{WORKS CITED}

Allaigre,Claude. "Introduction.” La Lozana Andaluza. By Francisco Delicado. Madrid: Cátedra, 2003. 17-166. Print.

Auerbach, Erich. "Gloria passionis." Literary Language and its Public in Latin Late Antiq uity and in the Middle Ages. Trans. Ralph Manheim. Princeton: Princeton UP, 1993. 67-82. Print.

Baranda, Consolación. "De 'Celestinas': Problemas metodológicos." Celestinesca 16.2 (1992): 3-32. Print.

Celestina comentada. Ed. Louise Fothergill-Payne. Salamanca: Ed. Univ. de Salamanca, 2002. Print.

Cervantes, Miguel de. El ingenioso hidalgo Don Quixote de la Mancha. Ed. John Jay Allen. Madrid: Cátedra, 2005. Print.

Delicado, Francisco. La Lozana andaluza. Ed. Claude Allaigre. Madrid: Cátedra, 2003. Print.

Deyermond, Alan D. The Petrarchan Sources of "La Celestina." London: Oxford UP, 1961. Print.

Fothergill-Payne, Louise. Seneca and Celestina. Cambridge: Cambridge UP, 1988. Print.

Fuchs, Barbara. Mimesis and Empire: The New World, Islam, and European Identities. Cambridge: Cambridge UP, 2004. Print.

Gilman, Stephen. The Spain of Fernando de Rojas. The Intellectual and Social Landscape of "La Celestina." Princeton: Princeton UP, 1972. Print.

Gryphius, Andreas. Dissertationes funebres oder Leichabdankungen. Ed. J.A. Steiger. Tübingen: Max Niemeyer, 2007. Print.

Harst, Joachim. Heilstheater. Figur des barocken Trauerspiels zwischen Gryphius und Kleist. Under review.

The Holy Bible. King James Version. Cambridge: Cambridge UP, 2006. Print. 
Kaplan, Gregory. The Evolution of Converso Literature: The Writings of the Converted Jews of Medieval Spain. Gainsville, FL: Florida UP, 2002. Print.

Lazarillo de Tormes. Ed. Francisco Rico. $16^{\text {th }}$ ed. Madrid: Cátedra 2006. Print.

Macpherson, Ian. "Secret Language in the Cancioneros: Some Courtly Codes." Bulletin of Hispanic Studies 62.1 (1985): 51-63. Print.

Miguel, Nicasio Salvador. "El presunto judaísmo de 'La Celestina." The Age of the Catholic Monarchs 1474-1516: Literary Studies in Memory of Keith Whinnom. Eds. Alan Deyermond and Ian Macpherson. Liverpool: Liverpool UP, 1989. 162-77. Print.

Nirenberg, David. "Figures of Thought and Figures of Flesh: 'Jews' and 'Judaism' in Late-Medieval Spanish Poetry and Politics.” Speculum 81 (2006): 398-426. Print.

Novum Testamentum Graece et Latine. Eds. Eberhard Nestle and Kurt Aland. Stuttgart: Deutsche Bibelgesellschaft, 2002. Print.

Rojas, Fernando de. La Celestina. Ed. Dorothy Severin. 15 ${ }^{\text {th }}$ ed. Madrid: Cátedra, 2005. Print.

San Pedro, Diego de. Cárcel de amor. Arnalte y Lucenda. Sermón. Ed. José Francisco Ruiz Casanova. Madrid: Cátedra, 2004. Print.

Seneca. Moral Essays. Trans. John W. Basore. Vol. 1. London: Heinemann 1928. Print.

Silva, Feliciano de. Segunda Celestina. Ed. Consolación Baranda. Madrid: Cátedra, 1988. Print.

Whinnom, Keith. La poesía amatoria de la época de los Reyes Católicos. Durham: Durham UP, 1981. Print.

“Diego de San Pedro's Stylistic Reform.” Bulletin of Hispanic Studies 37.1 (1960): 1-15. Print.

Zepp, Susanne. Herkunft und Textkultur. Über jüdische Erfahrungswelten in romanischen Literaturen 1499-1627. Göttingen: Vandenhoeck \& Ruprecht, 2010. Print. 